\title{
ASSESSING ALTERNATIVE WATER RESOURCES MANAGEMENT SCENARIOS IN ISLANDS OF THE AEGEAN ARCHIPELAGO, GREECE
}

\author{
C.A. KARAVITIS ${ }^{1, *}$ \\ N.A. SKONDRAS ${ }^{1}$ \\ E. MANOLI ${ }^{2}$ \\ D. ASSIMACOPOULOS ${ }^{2}$
}

Received: 05/12/11

Accepted: 27/07/12

\author{
${ }^{1}$ Department of Natural Resources Development \\ and Agricultural Engineering \\ Agricultural University of Athens, 75 lera Odos Av. \\ 11855 Athens, Greece \\ ${ }^{2}$ Section II, School of Chemical Engineering \\ National Technical University of Athens \\ 9 Heroon Polytechniou st., 15780 Athens, Greece
}

*to whom all correspondence should be addressed: e-mail: ckaravitis@aua.gr

\begin{abstract}
This effort discusses and evaluates alternative water management options to alleviate water stress and meet water needs in insular entities of the Aegean Archipelago, within the framework set by the principles of Integrated Water Resources Management (IWRM) and of the Water Framework Directive 2000/60/EC. Options are presented and assessed to determine integrated applicable strategies reflecting technical, economic, social and environmental constraints. The assessment is based on the application of the WaterStrategyMan Decision Support System (WSM DSS), developed under the Fifth Framework Programme, and is performed for six islands of the region. Results emphasize the need to understand the interconnections between social, technical, economic, and environmental problems in order to reach integrated solutions. In the dynamic context of current societies, pragmatic policy initiatives are needed to improve the means of preventing and addressing such issues, as well as new institutional structures to handle appropriately competing and conflicting water demands and development objectives.
\end{abstract}

KEYWORDS: Water Resources Management Scenarios, Decision Support Systems, Management in Island Systems, Aegean Islands, Greece.

\section{INTRODUCTION}

In response to policy requirements, integrated water resources planning and management has been placed at the focus of controversy and debate in the pertinent literature. It has been accepted that there is need for a larger systemic analysis of environmental issues is needed, accompanied with an enlargement of the traditional narrow planning and management approaches, and a growing sensitivity to decision-making problems associated with multi-objective, multi-purpose actions and multi-uses/users parameters. A framework for sustainable water exploitation and use should not only ideally, but necessarily, consider a mix of parameters, such as natural conditions (e.g. aridity, global change); variety of uses and their impacts (irrigation, urban uses, water quality, effluent control, etc.); sources of supply (surface, groundwater); and socio-demographic conditions (such as population growth, urbanization, industrialization, etc.). Furthermore, integrating surface water and groundwater resources within a basin and balancing competing regional demands with ecosystems' needs, are two vital issues that need to be addressed. The European Water Framework Directive 2000/60 EC (WFD) was an important step towards such Integrated Water Resources Management principles. However, despite its value, it has been characterized as highly complex in application, due to the strict time schedules and the inflexibility to approach various scientific, technical and practical issues in a variety of ways due to the lack of a single, standardized procedure, which could address all issues (Andreadakis, 2002). As a result, the whole approach is subjective and dependent of various 
premises and conditions, pertaining to the physical, social, scientific, political and legislative conditions in every area where the framework is applied. In several cases, these conditions render the implementation of the WFD a particularly challenging and difficult task, and limit the potential for developing effective solutions to address water management issues. Many areas of the Mediterranean region, where water is used in an unsustainable manner (Karavitis and Kerkides, 2002), are typical examples of this situation. Greece represents a more specific case.

In Greece, decisions for water resources management in practice declare a strong localized character: the authorities of each area plan and apply their own strategies separately, according to local specificities and perceived interests. Key determinants in this process include local development priorities, land use, spatio-temporal distribution of water supplies and conflicts among the different water use sectors. This lack of an "integrated water policy" results in fragmented, unsynchronized, and often unplanned efforts to address increasing water demands and resulting environmental pressures (Gerasidi, 2004). Such efforts hardly promote Integrated Water Resources Management values, as these have been expressed through the Global Water Partnership (2000; 2002). Another significant issue relates to the limited enforcement of the legal and institutional framework, due to the pronounced lack of integration and gaps in application procedures. Furthermore, and despite the recent reform that places water resources management exclusively under the authority of the Ministry of Environment, (Agorastakis, 2002), inflexible structures prevail (AUA, 2008; Demetropoulou et al., 2010). Relevant problems and difficulties, also in relation to the implementation of the WFD have been extensively discussed in Gerasidi, (2004); NCESD, (2001); Kyriazopoulou and Tselendis, (2003), Tatsis, (2008); Demetropoulou et al., (2010).

The most vulnerable and easily affected recipients of the various uncoordinated water-related policies and actions are the Greek islands (mainly those located in Aegean Sea). These areas face a plethora of challenges arising from specific geographical, physical and socio-economic factors, such as their isolation from mainland Greece, their small size, and their demographic profile, which presents wide seasonal variations (Beller et al., 1990; Karavitis and Kerkides, 2002). The conditions created by these factors (e.g. costly services due to lack of economies of scale, limited resources, environmental pressures of high seasonality, conflicts among water users) are crucial and have to be taken into account in the development of water resources management strategies and actions.

Water resources management in such areas can be facilitated through the application of different Decision Support Systems (DSS), aimed at analyzing desired goals and objectiv.es, and at assessing alternative solutions, in order to point out those that have the potential to meet most objectives and produce acceptable trade-offs (Turban, 1995; Grigg, 1996; Karavitis, 1999; Manoli et al., 2002). Nevertheless, the selection of the most suitable DSS or even the development of such a tool is an extremely challenging task (Mysiak et al., 2002). In the above context, this paper analyses different water supply and demand management options for meeting, in a sustainable way, water deficits experienced in islands of the Aegean Archipelago, Greece. The analysis is performed through the application of a Decision Support System, developed through the EC 5th Framework Programme, in order to simulate and evaluate potential interventions under plausible future scenarios, determining local water supply and demand.

\section{METHODOLOGY}

\subsection{The WaterStrategyMan Decision Support System}

The WaterStrategyMan (WSM) DSS was developed within the framework of WaterStrategyMan Project "Developing Strategies for Regulating and Managing Water Resources and Demand in Water Deficient Regions" - EVK1-CT-2001-00098, a project supported by the European Commission under the Fifth Framework Programme, as part of the Key Action Sustainable Management and Quality of Water within the Energy, Environment and Sustainable Development. The primary objective was to develop a decision support tool, able to simulate the behaviour of water resource systems under different scenarios of water availability and demand, and to assess the impact of water management options and strategic plans (The WaterStrategyMan DSS, 2004). The performance of every strategy is assessed by a multi-criteria based index (final score) that includes a variety of sub-indices such as water deficit minimization efficiency (performance index), cost retrieval degree, unsustainable water supply (environmental impacts) etc. Every criterion/sub-index receives preference based weights that depend on the desired output per case. Information on the project may be obtained at the Project Website (http://environ.chemeng.ntua.gr/wsm/). 


\subsection{The application of the WSM DSS in the areas of interest}

In the studies presented in this paper, the analysis of alternative interventions through the application of the WSM DSS was aimed at identifying the most suitable options or combinations of options for mitigating the disparity between water supply and demand, also considering local stakeholder preferences, environmental and economic criteria. The analysis was performed for six (6) islands - namely Ikaria, Samos, Sifnos, Kythnos, Syros and Paros - of the Aegean Archipelago (Table 1), for different scenarios (Table 4) and timeframes (Table 2).

Scenario development was employed to define a range of possible future conditions, focusing primarily on the key factors that can affect future water availability and demand. As identified through previous studies and consultation with local authorities, these concern population growth, density, location, priorities for local development (tourism and agriculture), as well as future climate conditions. Considering technical and social constraints and current infrastructure deficiencies, different options were identified for each island as potentially suitable to mitigate future water deficiencies.

\section{Areas of interest and analyzed cases}

The focal areas for this study are located in the Aegean Archipelago, Greece (Figure 1). Pertinent information for each island is presented in Tables 1,2 and 3. As described, the insular character and the distance from mainland Greece, along with the rather limited amount of rainfall or capacity to store rainfall water induce a series of problems, mostly relating to the limited opportunities for further development and the high cost for various services. With regard to socio-economic development, one of the most significant issues refers to water availability, supply and demand for a plethora of uses, such as households, tourism and agriculture. In order to meet these demands, three alternative demand and supply scenarios (Table 4) have been developed and analyzed per area (except for Paros, where a different approach was tested), in combination with relevant mitigation strategies. It is essential to be mentioned that:

1. the various scenarios and mitigation strategies were developed randomly based on the current conditions of each island and

2. the time horizon of the various scenarios do not represent the actual years. It just represents a series of randomly expressed variables regarding water availability.

For the analyses carried out for the islands of Syros and Paros additional key points were considered:

- $\quad$ For the case of Syros the analysis focuses solely on the agricultural sector. Currently, urban water demands are met through desalination; the adequate technical expertise and managerial skills of the local authorities in combination with the flexibility of the pertinent option, render the expansion of desalination capacity as the preferred alternative to meet future urban water demand.

- For the case of Paros, the analysis considers successive implementation of options, considering the relevant costs and technical constraints, since according to local stakeholders' interests, the prioritization of interventions was the main goal.

- Whenever cost information on the Strategies' was available (Sifnos and Syros) the relative graphs were prepared.

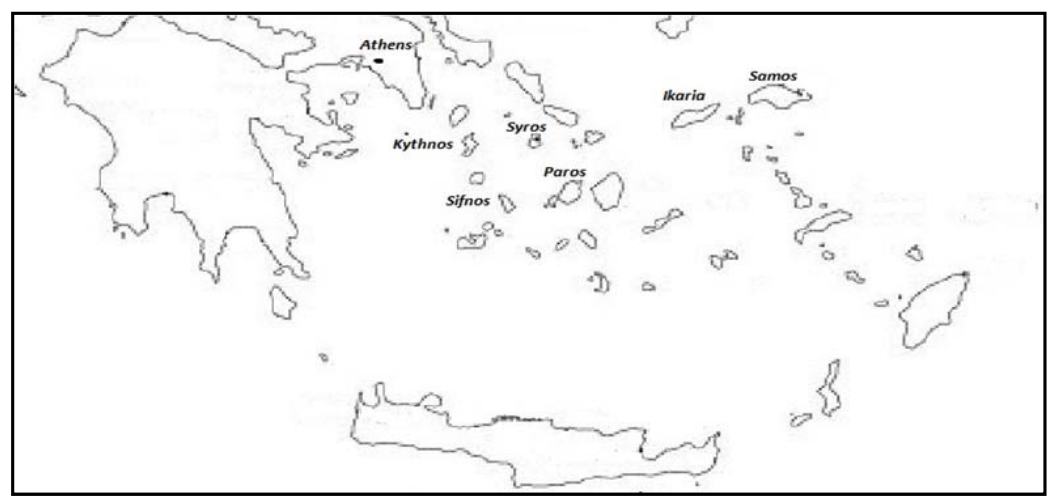

Figure 1. The Central Southern part of the Aegean Archipelago, depicting also the areas of study 
Table 1. Basic Descriptive Data of the island areas

\begin{tabular}{|c|c|c|c|c|c|c|}
\hline Island & Location & Prefecture & Region & Area $\left(\mathrm{km}^{2}\right)$ & $\begin{array}{c}\text { Population } \\
(2001)\end{array}$ & $\begin{array}{l}\text { Growth Rate } \\
\text { (1991 -2001) }\end{array}$ \\
\hline Ikaria & $\begin{array}{l}37^{\circ} 35^{\prime} 0^{\prime \prime} \mathrm{N} \\
26^{\circ} 10^{\prime} 0^{\prime \prime} \mathrm{E}\end{array}$ & Samos & $\begin{array}{c}\text { North } \\
\text { Aegean }\end{array}$ & 255 & 8354 & $7.50 \%$ \\
\hline Samos & $\begin{array}{l}37^{\circ} 44^{\prime} 0^{\prime \prime} \mathrm{N} \\
26^{\circ} 50^{\prime} 0^{\prime \prime} \mathrm{E}\end{array}$ & Samos & $\begin{array}{c}\text { North } \\
\text { Aegean }\end{array}$ & 477.4 & 33814 & $2.19 \%$ \\
\hline Sifnos & $\begin{array}{l}36^{\circ} 59^{\prime} 0^{\prime \prime} \mathrm{N} \\
24^{\circ} 40^{\prime} 0^{\prime \prime} \mathrm{E}\end{array}$ & Cyclades & $\begin{array}{c}\text { South } \\
\text { Aegean }\end{array}$ & 74 & 2574 & $31.30 \%$ \\
\hline Kythnos & $\begin{array}{l}37^{\circ} 23^{\prime} 0^{\prime \prime} \mathrm{N} \\
24^{\circ} 25^{\prime} 0^{\prime \prime} \mathrm{E}\end{array}$ & Cyclades & $\begin{array}{c}\text { South } \\
\text { Aegean }\end{array}$ & 99.4 & 1608 & $-1.47 \%$ \\
\hline Syros & $\begin{array}{l}37^{\circ} 27^{\prime} 0^{\prime \prime} \mathrm{N} \\
24^{\circ} 54^{\prime} 0^{\prime \prime} \mathrm{E}\end{array}$ & Cyclades & $\begin{array}{c}\text { South } \\
\text { Aegean }\end{array}$ & 84 & 19782 & $-0.44 \%$ \\
\hline Paros & $\begin{array}{l}37^{\circ} 5^{\prime} 0^{\prime \prime} \mathrm{N} \\
25^{\circ} 9^{\prime} 0^{\prime \prime} \mathrm{E}\end{array}$ & Cyclades & $\begin{array}{c}\text { South } \\
\text { Aegean }\end{array}$ & 195 & 12853 & $31.40 \%$ \\
\hline
\end{tabular}

Table 2. Descriptive data for the areas

\begin{tabular}{lcccccc}
\hline Island & $\begin{array}{c}\text { Annual Tourist } \\
\text { Stays } \\
\text { (individuals) }\end{array}$ & $\begin{array}{c}\text { Mean Annual } \\
\text { Temperature } \\
\left({ }^{\circ} \mathbf{C}\right)\end{array}$ & $\begin{array}{c}\text { Mean Annual } \\
\text { Rainfall } \\
(\mathbf{m m})\end{array}$ & $\begin{array}{c}\text { Agricultural } \\
\text { Area }\left(\mathbf{k m}^{2}\right)\end{array}$ & $\begin{array}{c}\text { Farmed Animals } \\
\text { in Tonnes of } \\
\text { Biomass } / \mathbf{~ k m}^{2}[*]\end{array}$ & $\begin{array}{c}\text { Scenarios time } \\
\text { horizon }\end{array}$ \\
\hline Ikaria & $51564(2006)$ & $18.9(1980-2001)$ & $631.8(1980-2001)$ & $33.55(2005)$ & $9.33(2005)$ & $2009-2023$ \\
\hline Samos & $1411797(2004)$ & $18.3(1988-1993)$ & $703.7(1988-1993)$ & $206.45(2004)$ & $4.69(2004)$ & $2007-2012$ \\
\hline Sifnos & $10077(2005)$ & $18.4(1946-1972)$ & $474.4(1946-1972)$ & $13(2003)$ & $9.97(2003)$ & $2007-2012$ \\
\hline Kythnos & $1665(2006)$ & $18.6(1969-1990)$ & $391.8(1930-1990)$ & $49.37(2000)$ & $12.18(2000)$ & $2008-2020$ \\
\hline Syros & $85285(1998)$ & $18.6(1969-1990)$ & $391.8(1930-1990)$ & $17.8(2002)$ & $12.75(2002)$ & $2004-2015$ \\
\hline Paros & - & $18.4(1946-1972)$ & $474.4(1946-1972)$ & $63.5(2004)$ & $8.32(2004)$ & $2003-2040$ \\
\hline \multicolumn{5}{c}{ * Mean weight per animal (Zervas et al., 2000): Pigs = 140 kg, Sheep and Goats = 65 kg, Cattle, Horses, } \\
\multicolumn{7}{c}{ Donkeys = 500 kg, Poultry = 3.5 kg, Rabbits = 7 kg }
\end{tabular}

Table 3. Water-related information

\begin{tabular}{lccccc}
\hline Islands & $\begin{array}{c}\text { Storage } \\
\text { Facilities }\end{array}$ & Boreholes & $\begin{array}{c}\text { Dams - } \\
\text { Reservoirs [*] }\end{array}$ & $\begin{array}{c}\text { Water Demand } \\
\left(\mathbf{m i l l i o n}^{\mathbf{3}} \mathbf{\mathbf { y r } ^ { - 1 }}\right)\end{array}$ & $\begin{array}{c}\text { Mean Water } \\
\text { Price }\left(\boldsymbol{(} \mathbf{~ m}^{-\mathbf{3}}\right) \\
{\left[{ }^{* *}\right]}\end{array}$ \\
\hline Ikaria & $>40$ & 16 & $3+(4)$ & 0.9 & 0.44 \\
\hline Samos & 41 & 324 & $2+(2)$ & - & - \\
\hline Sifnos & 17 & 19 & 0 & 0.34 & 1.68 \\
\hline Kythnos & 15 & 13 & $(1)$ & 0.16 & 0.93 \\
\hline Syros & 46 & 23 & 0 & 0.85 & 2.1 \\
\hline Paros & - & 500 & $(1)$ & 2 & 1.9 \\
\hline
\end{tabular}

* The number in brackets indicates the under construction future infrastructure.

** The mean value of all the recorded water sale prices per island

\section{WSM DSS APPLICATION AND ANALYSIS OF RESULTS}

The application of the WSM Decision Support System in thefollowing areas aimed at identifying the most suitable solution/strategies for each island, in order to meet local water demands, and limit future deficits to the largest extent possible. This has been achieved by comparing the available strategies for each of the previously presented scenarios. The results are presented and discussed in the following paragraphs. In $\backslash$ table 5 .the letters $(A, B, C)$ refer to the scenario as described in table 4 , whereas the numbers $(1,2,3$, and 4$)$ indicate the corresponding strategy. To clear up results the performance of each strategy under the conditions of the three pertinent scenarios was estimated. 
Table 4. Applied scenarios per island

\begin{tabular}{|c|c|c|c|c|c|c|}
\hline \multirow[b]{2}{*}{ Islands } & \multicolumn{6}{|c|}{ Scenario A } \\
\hline & $\begin{array}{c}\text { Hydrological year - } \\
\% \text { of annual water } \\
\text { resources } \\
\text { recharge }\end{array}$ & $\begin{array}{c}\text { Tourism } \\
\text { development }\end{array}$ & $\begin{array}{l}\text { Population } \\
\text { growth }\end{array}$ & $\begin{array}{l}\text { Agricultural } \\
\text { area }\end{array}$ & $\begin{array}{l}\text { Farmed } \\
\text { Animals }\end{array}$ & $\begin{array}{c}\text { Available } \\
\text { Water } \\
\text { Resources for } \\
\text { Irrigation }\end{array}$ \\
\hline Ikaria & Normal $-100 \%$ & $+2 \% / y$ & $+0.77 \% / y$ & $-2 \% / y$ & - & - \\
\hline Samos & Normal - $100 \%$ & $+4 \% / y$ & $0 \%$ & UnC & UnC & - \\
\hline Sifnos & Normal $-100 \%$ & $+4 \% / y$ & $0 \%$ & UnC & UnC & - \\
\hline Kythnos & Normal - $100 \%$ & $\begin{array}{l}+2 \% / y(2008- \\
2015),+4 \% / y \\
(2015-2020)\end{array}$ & $0 \%$ & UnC & UnC & - \\
\hline Syros & - & - & - & UnC & - & UnC \\
\hline Paros & Normal $-100 \%$ & $+1.5 \% / y$ & $+1.5 \% / y$ & - & - & - \\
\hline \multirow[b]{2}{*}{ Islands } & \multicolumn{6}{|c|}{ Scenario B } \\
\hline & $\begin{array}{l}\text { Hydrological year- } \\
\% \text { of annual water } \\
\text { resources recharge }\end{array}$ & $\begin{array}{c}\text { Tourism } \\
\text { development }\end{array}$ & $\begin{array}{l}\text { Population } \\
\text { growth }\end{array}$ & $\begin{array}{l}\text { Agricultural } \\
\text { area }\end{array}$ & $\begin{array}{l}\text { Farmed } \\
\text { Animals }\end{array}$ & $\begin{array}{c}\text { Available } \\
\text { Water } \\
\text { Resources } \\
\text { for Irrigation }\end{array}$ \\
\hline Ikaria & Highly Dry $-80 \%$ & $+2 \% / y$ & $+0.77 \% / y$ & $-2 \% / y$ & - & Not analysed \\
\hline Samos & $\begin{array}{c}\text { Dry }-90 \% \text { (1st } \\
\text { year), Highly Dry - } \\
80 \% \text { (2nd year), } \\
\text { normal - } \\
100 \% \text { (Rest) } \\
\end{array}$ & $0 \%$ & $0 \%$ & $0 \%$ & $0 \%$ & Not analysed \\
\hline Sifnos & $\begin{array}{c}\text { Dry }-90 \% \text { (1st } \\
\text { year), Highly Dry - } \\
80 \% \text { (2nd year), } \\
\text { normal - } \\
100 \% \text { (Rest) } \\
\end{array}$ & $0 \%$ & $0 \%$ & $0 \%$ & $0 \%$ & Not analysed \\
\hline Kythnos & $\begin{array}{c}\text { Normal - 100\% } \\
(1,2,4,6-8,11-13), \\
\text { Dry - } 90 \% \quad(3,9- \\
\text { 10),Highly Dry - } \\
80 \%(5) \\
\end{array}$ & $0 \%$ & $0 \%$ & $0 \%$ & $0 \%$ & Not analysed \\
\hline Syros & Not analysed & Not analysed & Not analysed & $0 \%$ & - & $-20 \%$ \\
\hline Paros & & & $\mathrm{X}$ & & & \\
\hline \multirow[b]{2}{*}{ Islands } & \multicolumn{6}{|c|}{ Scenario C } \\
\hline & $\begin{array}{l}\text { Hydrological year- } \\
\% \text { of annual water } \\
\text { resources recharge }\end{array}$ & $\begin{array}{c}\text { Tourism } \\
\text { development }\end{array}$ & $\begin{array}{l}\text { Population } \\
\text { growth }\end{array}$ & $\begin{array}{l}\text { Agricultural } \\
\text { area }\end{array}$ & $\begin{array}{l}\text { Farmed } \\
\text { Animals }\end{array}$ & $\begin{array}{c}\text { Available } \\
\text { Water } \\
\text { Resources for } \\
\text { Irrigation } \\
\end{array}$ \\
\hline Ikaria & Highly Dry $-80 \%$ & $+4 \% / y$ & $+0.77 \% / y$ & UnC & - & Not analysed \\
\hline Samos & Normal - $100 \%$ & $+4 \% / y$ & UnC & $-5 \% / y$ & $+2 \% / y$ & Not analysed \\
\hline Sifnos & Normal $-100 \%$ & $+4 \% / y$ & UnC & $-5 \% / y$ & $+2 \% / y$ & Not analysed \\
\hline Kythnos & Dry $-90 \%$ & $+2 \% / y$ & UnC & $-3 \% / y$ & $+1 \% / y$ & Not analysed \\
\hline Syros & Not analysed & Not analysed & $\begin{array}{c}\text { Not } \\
\text { analysed }\end{array}$ & $0 \%$ & - & $-40 \%$ \\
\hline Paros & & & $\mathrm{X}$ & & & \\
\hline
\end{tabular}

4.1. Ikaria Island

The alternative strategies, for eliminating the potential water deficits according to the described scenarios (Table 4), include (Kavadias, 2008): 
Strategy 1 (Maintaining the current water management interventions):

1. Sixteen (16) officially registered boreholes; 2. Two dams on Halari and Myrsonas streams, Municipality of Raches, and a reservoir of total capacity of $800,000 \mathrm{~m}^{3} ; 3$. A reservoir with capacity of $60,000 \mathrm{~m}^{3}$ in the municipality of Aghios Kyrikos (water losses have been observed due to construction deficiencies); 4. Many unofficial wells and boreholes.

Strategy 2:

1. Construction of two extra dams in the municipalities of Raches and Evdilos. 2. Reconstruction of the deficient reservoir in the municipality of Aghios Kyrikos. Total estimated cost of implementation: 2.5 million $€$.

Strategy 3:

In addition to the option proposed above: 1. Construction of two desalination units in the municipalities of Evdilos and Raches. 2. 40\% substitution of crops with other, less water intensive cultivations. Total estimated cost of implementation: 3.5 million $€$.

According to the simulation outcomes, presented in Table 5, Strategy 2 (Construction of two dams in the municipalities of Raches and Evdilos, and reconstruction of the flawed reservoir in the municipality of Agios Kirykos), is the most suitable strategy for meeting water demands in the island of Ikaria as it presents the higher performance score, and entails the lowest financial and environmental costs. Strategy 3 where two additional desalination units are proposed, can meet water demand in a more effective way than Strategy 1 (sustaining the current conditions), as scenario projections denote a demand increase and limited available supply from freshwater resources. The high score of Strategy 2 for the first (most optimistic) scenario portrays the need for an immediate capacity expansion, as the demand cannot be sufficiently met through existing infrastructure. Furthermore, performance scores for the other scenarios indicate that the corresponding costs are relatively low (Kavadias, 2008). As presented in Table 6, all strategies have almost similar scores for the three scenarios. It can thus be concluded that scenario assumptions have little impact on the performance of the three strategies, and that the performance of the analysed options is independent of interannual rainfall variations and population growth estimates.

\subsection{Samos Island}

The proposed alternative strategies for meeting the local water demand include (Alexiou, 2007):

\section{Strategy 1}

The construction of 1. a dam in Karvouni 2. a water reservoir in Hydrousa, and 3. their connection to the local water supply and irrigation networks.

\section{Strategy 2}

1. The construction of a dam in Karvouni and a water reservoir in Hydrousa, and their connection to the local water supply and irrigation network. 2. The construction of two desalination units in the locations of Marathokampos and Vathy $\left(950 \mathrm{~m}^{3} \mathrm{~d}^{-1}\right.$ and $850 \mathrm{~m}^{3} \mathrm{~d}^{-1}$ for the first scenario and $1100 \mathrm{~m}^{3} \mathrm{~d}^{-1}$ and $950 \mathrm{~m}^{3} \mathrm{~d}^{-1}$ for the other two scenarios of Table 4). 3. The $80 \%$-replacement of horticultural plants (water demanding) with other, less water intensive (orchards). 4. A $50 \%$ increase of the current water price.

According to the outcomes, presented in Table 5 Strategy 2 appears most suitable. It has to be stated that the environmental impact (negative effects - pressures) for both strategies have not been included in the analysis. Such an inclusion could differentiate the current results. Furthermore, regarding Strategy 2, it cannot fully address water deficit problems. Full coverage of the assessed water needs, would entail significant costs. Although both strategies rank positively with respect to baseline conditions (i.e. no interventions), both present different economic and technical constraints, such as significant construction timeframes and investment costs, issues that need further analysis (Alexiou, 2007).

\subsection{Sifnos Island}

The proposed alternative strategies for covering water demand are (Athanasopoulos, 2007): 


\section{Strategy 1}

1. Construction of a desalination unit for the settlement of Kamares. Its capacity is estimated at $400 \mathrm{~m}^{3} \mathrm{~d}^{-1}$ for the first scenario and $450 \mathrm{~m}^{3} \mathrm{~d}^{-1}$ for the other two scenarios. 2. Restoration of a dam in the same area that had been damaged in 2003. The estimated cost of interventions is $400,000 €$ for the desalination unit and $700,000 €$ for the dam restoration.

\section{Strategy 2}

1. Construction of a desalination unit for the settlement of Kamares. Its capacity is estimated at $450 \mathrm{~m}^{3} \mathrm{~d}^{-1}$ for the first scenario and $500 \mathrm{~m}^{3} \mathrm{~d}^{-1}$ for the other two scenarios. 2. Replacement of water intensive crops with less water demanding ones, in $80 \%$ of the currently irrigated areas.

According the results presented in Table 5, Strategy 1 , which includes the rehabilitation of the damaged storage reservoir seems to be the best solution for all three scenarios. Low scores are attributed to the inability to meet irrigation demands; however, domestic water needs, which are prioritized, are fully met. Strategy 2 , which includes crop substitution, obtains lower scores, as it cannot fully meet both irrigation and domestic demands. These results are expected, since the dam can provide a greater amount of water than crop substitution can save. Strategy 1 is also more economically efficient, since the corresponding NPV is higher (Graph 1, d =4\%), and can thus be considered a beneficial investment despite potential disadvantages (Athanasopoulos, 2007).

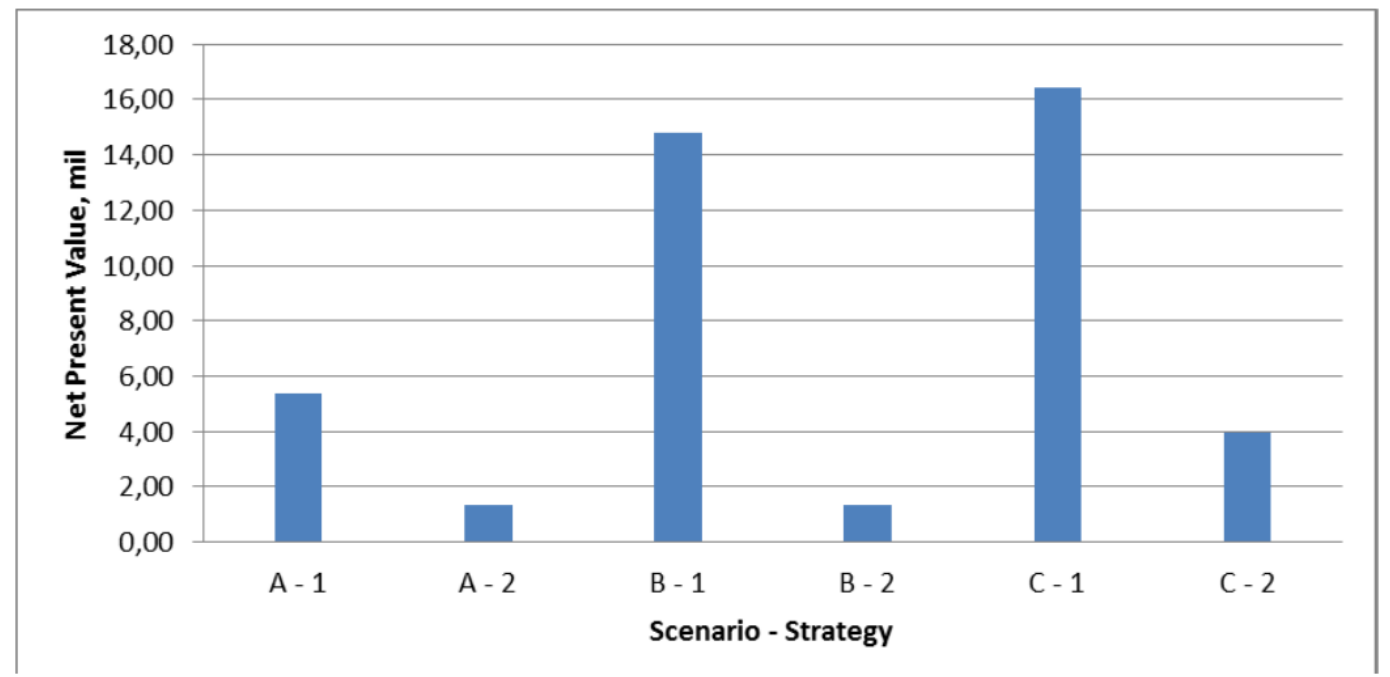

Graph 1. Net Present Value of the proposed strategies for Sifnos Island - Discount rate: $4 \%$

\subsection{Kythnos Island}

The proposed alternative strategies for covering water demand are (Papamanthos, 2007):

\section{Strategy 1: Sustaining the current conditions:}

No new water related infrastructure or policies.

\section{Strategy 2}

1. The construction of a dam in the valley of Episkopi. 2. The construction of a desalination unit $\left(500 \mathrm{~m}^{3} \mathrm{~d}^{-1}\right)$ between Meriha and Martinakia. Total Cost: 5.5 million $€$.

\section{Strategy 3}

1. The construction of the previous mentioned desalination unit. 2. The restoration of the current water network to reduce leakage. 3. A 50\%-change of irrigation methods from sprinkler to drip.

\section{Strategy 4}

1. The construction of the aforementioned desalination unit. 2. The restoration of the current water network. 3. An 105\%-increase of the current water price. 
The results for Kythnos Island (Table 5), portray that no single strategy of those formulated is the most suitable under all the scenarios. Strategy 1 (which includes no further interventions on the current water system) has the worst performance, since the current system cannot respond to the changing conditions assumed in the analyzed scenarios. Results for Strategies 3 and 4 are similar for scenarios $\mathrm{A}$ and $\mathrm{C}$, and thus Strategy 4 can be considered an appropriate solution for addressing water deficit issues for all scenarios. Strategy 2 is ranked third in all scenarios because of environmental issues stemming from the construction of the dam and its high construction costs. Furthermore, management options included in Strategies 3 and 4 are beneficial under all conditions and thus constitute interventions that need to be prioritized (Papamanthos, 2007).

Table 5. Results for five islands

\begin{tabular}{|c|c|c|c|}
\hline \multicolumn{2}{|l|}{ Ikaria } & \multicolumn{2}{|c|}{ Sifnos } \\
\hline Scenario - Strategy & Total Score & Scenario - Strategy & Total Score \\
\hline$A-1$ & 0.571 & $A-1$ & 0.429 \\
\hline A - 2 & 0.751 & $A-2$ & 0.357 \\
\hline A - 3 & 0,357 & B - 1 & 0.429 \\
\hline B - 1 & 0.571 & B - 2 & 0.357 \\
\hline B - 2 & 0.643 & C - 1 & 0.429 \\
\hline$B-3$ & 0.572 & C - 2 & 0.286 \\
\hline C - 1 & 0.572 & & \\
\hline C - 2 & 0.643 & \multicolumn{2}{|c|}{ Samos } \\
\hline$C-3$ & 0.573 & Scenario - Strategy & Total Score \\
\hline \multicolumn{2}{|l|}{ Kythnos } & A - 1 & 0.5714 \\
\hline Scenario - Strategy & Total Score & A - 2 & 0.6 \\
\hline A - 1 & 0.25 & $B-1$ & 0.5714 \\
\hline A - 2 & 0.75 & B - 2 & 0.6 \\
\hline A - 3 & 0.751 & $C-1$ & 0.5714 \\
\hline$A-4$ & 0.751 & C - 2 & 0.6 \\
\hline$B-1$ & 0 & & \\
\hline B - 2 & 0.0709 & \multicolumn{2}{|c|}{ Syros } \\
\hline$B-3$ & 0.543 & Scenario - Strategy & Total Score \\
\hline B - 4 & 0.751 & B - 1 & 1 \\
\hline C - 1 & 0.25 & B - 2 & 0,583 \\
\hline C - 2 & 0.291 & C - 1 & 0,473 \\
\hline C - 3 & 0.5246 & C - 2 & 0,165 \\
\hline$C-4$ & 0.5237 & Current & 1 \\
\hline
\end{tabular}

\subsection{Syros Island}

The first scenario (Table 5) is used as a reference point, as currently no water deficit is experienced. Strategies are thus formulated only for the two other scenarios in Table 6, and focus on meeting local irrigation demands (Michos, 2004):

\section{Strategy 1}

The construction of shallow boreholes in selected locations, including 27 boreholes for the second scenario and 45 boreholes for the third, at cost of $30,000 €$ each.

The results obtained from the application of the WSM DSS in Syros island are presented in Table 5. Strategy 1, which includes borehole drilling is dominant in both scenarios, despite the fact that it cannot fully meet water needs estimated for Scenario C, which is considered pessimistic, particularly with regard to summer conditions. On the other hand, the scores of Strategy 2, which includes crop 
substitution, demonstrate limited contribution in mitigating the disparity between water supply and demand. A comparison of the NPV of the two solutions (Graph 2, $d=4 \%$ ) yields the same conclusion: Strategy 1 presents lower costs, and can thus be considered a good investment for the area (Michos, 2004).

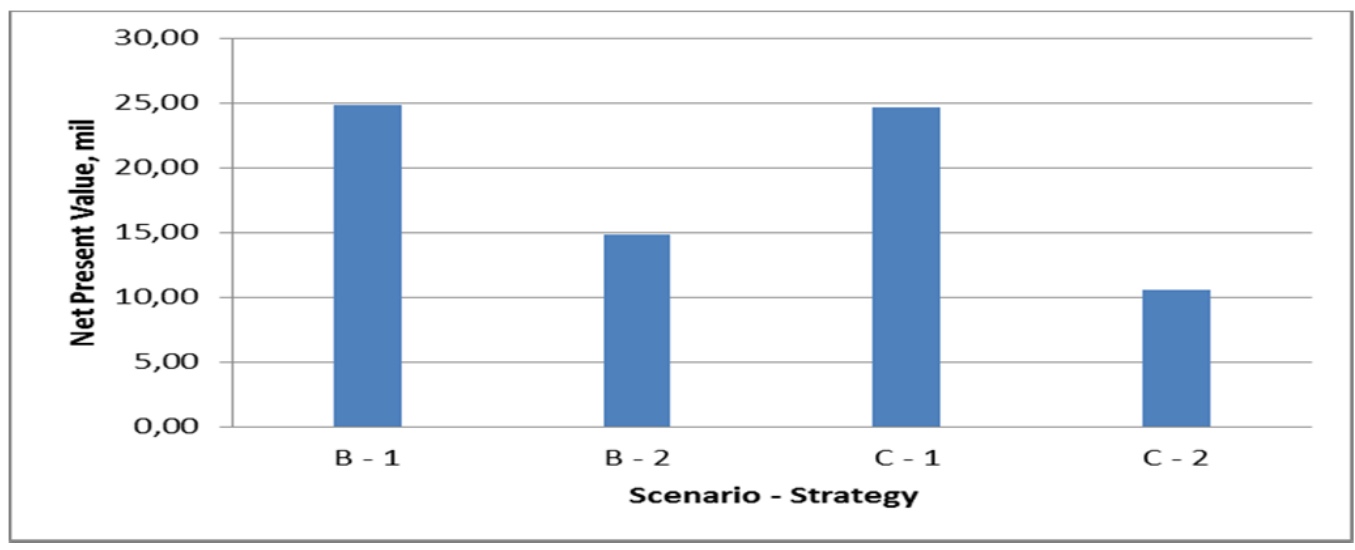

Graph 2. Present Values of the simulated strategies of Syros Island

\subsection{Paros Island}

The proposed alternative options for covering water demand are (Gerasidi, 2004):

Alternative Option 1

The construction of 8 boreholes $\left(20 \mathrm{~m}^{3} \mathrm{~h}^{-1}, 14 \mathrm{~h} \mathrm{~d}^{-1}\right)$.

Alternative Option 2

Installation of flow reduction devices and water efficient appliances in $70 \%$ of households.

Alternative Option 3

Decrease of the distribution network losses by $8 \%$.

Alternative Option 4

Decrease of distribution network losses by $12 \%$.

Alternative Option 5

Construction of a dam $\left(180,000 \mathrm{~m}^{3}\right)$.

Alternative Option 6

Construction of a desalination unit $\left(1600 \mathrm{~m}^{3} \mathrm{~d}^{-1}, 170 \mathrm{~d} \mathrm{yr}^{-1}\right)$

The strategies that derive from these options are presented in Table 6.

Table 6. Strategies and solutions applied in Paros Island

\begin{tabular}{lcccccc}
\hline Options & Option 1 & Option 2 & Option 3 & Option 4 & Option 5 & Option 6 \\
\hline Strategies & & & & & & - \\
\hline Strategy 1 & $\mathrm{X}$ & - & - & - & - & - \\
\hline Strategy 2 & $\mathrm{X}$ & $\mathrm{X}$ & - & - & - & - \\
\hline Strategy 3 & $\mathrm{X}$ & $\mathrm{X}$ & $\mathrm{X}$ & - & - & - \\
\hline Strategy 4 & $\mathrm{X}$ & $\mathrm{X}$ & - & $\mathrm{X}$ & - & - \\
\hline Strategy 5 & $\mathrm{X}$ & $\mathrm{X}$ & - & $\mathrm{X}$ & $\mathrm{X}$ & - \\
\hline Strategy 6 & $\mathrm{X}$ & $\mathrm{X}$ & - & $\mathrm{X}$ & $\mathrm{X}$ & $\mathrm{X}$ \\
\hline
\end{tabular}

(X) Applied, (-) Not Applied

The various strategies are applied gradually every time water deficit occurs due to the population and tourists water demand (Graph 3). The solutions are assessed via their performance on two indices. An Unsustainable Water Production Index $[<40 \%]$ and a performance index, relative to the coverage of water demand [minimum coverage $90 \%$ of water deficit] (Gerasidi, 2004).

According to the total WSM DSS results of the first Index (Unsustainable Water Production) for Paros Island (Table 7) the higher scores (most preferred) are obtained for strategies that do not 
include significant technical interventions, such as borehole drilling and network rehabilitation. On the other hand, performance on domestic demand coverage is better for strategies that enhance water supply, if potential environmental impacts are not considered. Nevertheless, the crosscomparison of results obtained for Strategies 4 and 5 , which have similar performance, offers an interesting conclusion: immediate, easy-to-implement and low-cost actions, of medium environmental impact can often produce results similar to large-scale interventions, which are expensive, time consuming and can pose significant threats to local ecosystems (Gerasidi, 2004).

Table 7. The results of WSM DSS for Paros Island

\begin{tabular}{|c|c|c|c|c|c|c|c|}
\hline Index/Criteria & $\begin{array}{l}\text { Current } \\
\text { Conditions }\end{array}$ & S1 & S2 & S3 & S4 & S5 & S6 \\
\hline \multicolumn{8}{|c|}{ Unsustainable Water Production } \\
\hline Total & 0.000 & 0.000 & 0.000 & 0.002 & 0.002 & 0.001 & 0.001 \\
\hline \multicolumn{8}{|c|}{ Water Demand Fulfiilment } \\
\hline Total & 0.000 & 0.000 & 0.004 & 0.009 & 0.019 & 0.025 & 0.148 \\
\hline $\begin{array}{l}\text { TOTAL } \\
\text { SCORE }\end{array}$ & 0.000 & 0.000 & 0.002 & 0.006 & 0.012 & 0.015 & 0.089 \\
\hline
\end{tabular}

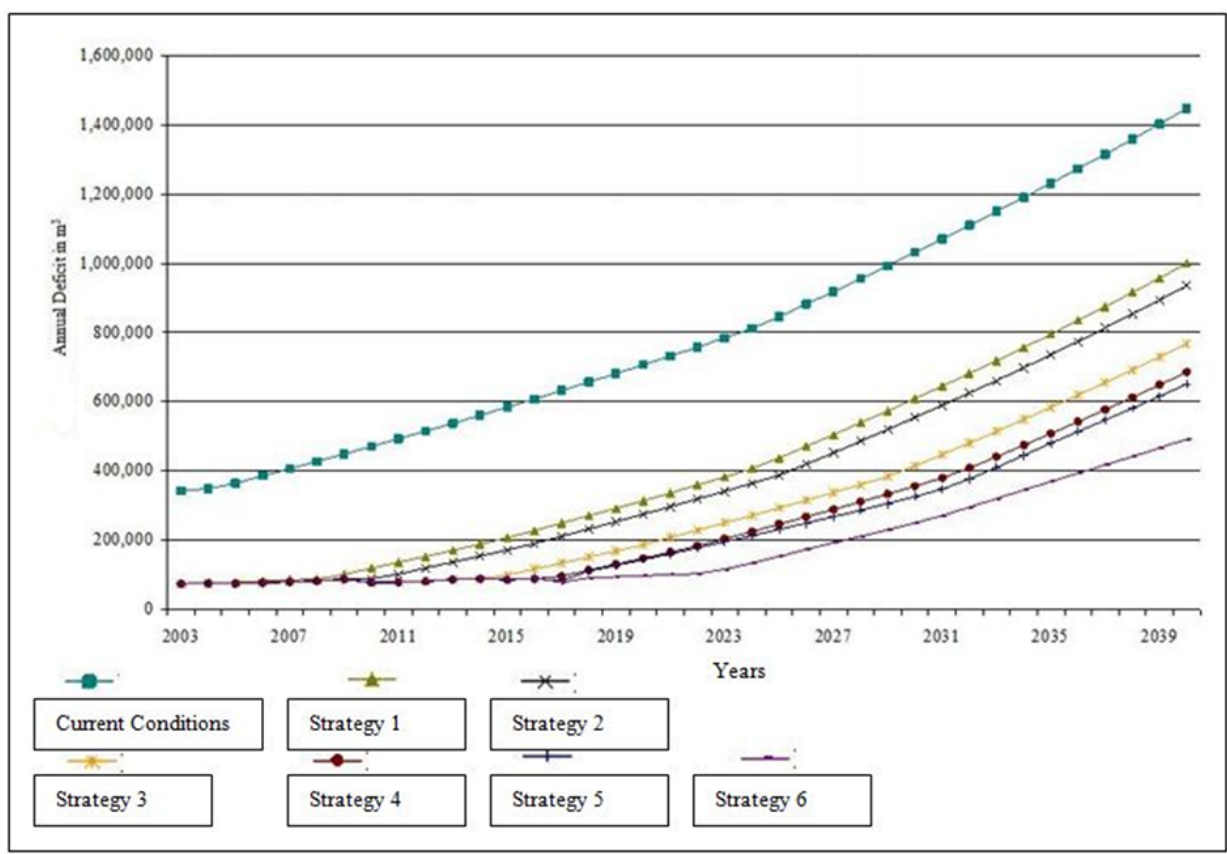

Graph 3. Annual water deficit per strategy for Paros Island

\section{CONCLUSIONS AND RECOMMENDATIONS}

The water related problems of each island of the area of interest, have been approached in an integrated as possible manner, by taking into account resource availability, environmental considerations and financial data. Political conditions and social acceptability though were not assessed. The WSM DSS results can be summarized as follows:

1. The strategies that were graded as more preferred in each island (Table 8) were the ones that balanced both the demand coverage, as well as the sustainable use of the area's water resources and the implementation cost of each strategy.

2. Best-performing strategies are mainly those that integrate water supply and demand management options. 
Table 8. Suggested strategies according to simulation results

\begin{tabular}{|c|c|c|}
\hline \multirow{2}{*}{ Islands } & \multicolumn{2}{|l|}{ Selected Strategies } \\
\hline & Demand Management & Supply Management \\
\hline Ikaria & NONE & $\begin{array}{l}\text { 1. Construction of two dams in the municipalities } \\
\text { of Raches and Evdilos. } \\
\text { 2. Rehabilitation of storage reservoir in the } \\
\text { municipality of Agios Kyrikos. }\end{array}$ \\
\hline Samos & $\begin{array}{l}\text { 1. } 80 \% \text { substitution of horticultural } \\
\text { plants with other, less water } \\
\text { intensive crops } \\
\text { 2. } 50 \% \text { increase of current domestic } \\
\text { and irrigation water price. }\end{array}$ & $\begin{array}{l}\text { 1. Construction of a dam in Karvouni and a water } \\
\text { reservoir in Hydrousa, and the water } \\
\text { conveyance system to the local water supply } \\
\text { and irrigation network. } \\
\text { 2. Construction of two desalination units in } \\
\text { Marathokampos and Vathy. }\end{array}$ \\
\hline Sifnos & NONE & $\begin{array}{l}\text { 1. Construction of a desalination unit in Kamares } \\
\text { (capacity of } 400 \mathrm{~m}^{3} \mathrm{~d}^{-1} \text { for the first scenario and } \\
450 \mathrm{~m}^{3} \mathrm{~d}^{-1} \text { for the other two scenarios). } \\
\text { 2. Rehabilitation of a dam damaged in } 2003 \text {. }\end{array}$ \\
\hline Kythnos & $\begin{array}{l}\text { 1. } 105 \% \text { increase of the current } \\
\text { domestic and irrigation water price }\end{array}$ & $\begin{array}{l}\text { 1. Construction of a desalination unit }\left(500 \mathrm{~m}^{3} \mathrm{~d}^{-1}\right) \\
\text { between Merihas and Martinakia. } \\
\text { 2. Water network rehabilitation. }\end{array}$ \\
\hline Syros & NONE & $\begin{array}{l}\text { Construction of shallow boreholes in selected } \\
\text { locations. }\end{array}$ \\
\hline Paros & $\begin{array}{l}\text { 1. Installation of water saving } \\
\text { appliances in } 70 \% \text { of the } \\
\text { households. } \\
2 . \quad \text { Network rehabilitation to reduce } \\
\text { losses by } 12 \%\end{array}$ & $\begin{array}{l}\text { 1. Construction of eight boreholes }\left(20 \mathrm{~m}^{3} \mathrm{~h}^{-1} \text {, }\right. \\
\left.14 \mathrm{~h} \mathrm{~d}^{-1}\right) \text {. } \\
\text { 2. Construction of a dam }\left(180,000 \mathrm{~m}^{3}\right) \text {. } \\
\text { 3. Construction of a desalination unit }\left(1600 \mathrm{~m}^{3} \mathrm{~d}^{-1} \text {, }\right. \\
\left.170 \mathrm{~d} \mathrm{yr}^{-1}\right)\end{array}$ \\
\hline
\end{tabular}

The results illustrate the importance of an integrated and balanced approach of water related issues, that can lead to sustainable patterns in water use in Greek islands. Areas stressed due to intensive tourism and agriculture. Such approaches need to exploit technological (construction options supply management), ecological (available water resources) and social (conservation - demand management) capacities for change.

The pertinent approaches require specialized tools in order to be achieved. Decision Support Systems like WSM DSS can be of great help to decision and policy makers by presenting the performance of the available alternative options under numerous scenarios of future conditions.

\section{REFERENCES}

Agorastakis G. (2002) Water Reservoir Management in Crete, Greece. Presented in the Conference: Artificial Wetlands and Water Reservoirs in Crete, Greece.

Alexiou M. (2007) Water Resources Management in Island Systems: Water Supply Options and Costs in Samos Island, Greece. Bachelor Thesis at the Department of Natural Resources Management and Agricultural Engineering, Agricultural University of Athens, Greece (in Greek).

Andreadakis A. (2002) The Need for Synchronized Action in the Application of Water Framework Directive 2000/60 EC. Department of Civil Engineering, National Technical University of Athens, Greece.

Athanasopoulos G. (2007) Water Resources Management in Island Systems: Water Supply Options in Sifnos Island, Greece. Bachelor Thesis at the Department of Natural Resources Management and Agricultural Engineering, Agricultural University of Athens, Greece (in Greek).

AUA (Agricultural University of Athens) (2008) Department of Natural Resources and Agricultural Engineering, Water Resources Management Sector, Co-ordinator: C.A. Karavitis: Technical Support to the Central Water Agency for the Development of a Drought Master for Greece and an Immediate 
Drought Mitigation Plan, Contract No. 10889/11/07 /2007 Ministry of Planning, Public Works and the Environment, Athens, Greece (in Greek)

Beller W., D'Ayala P. and Hein P. (1990) 'Sustainable Development and Environmental Management of Small Islands', Man and the Biosphere Series, UNESCO.

Demetropoulou L., Nikolaidis, N., Papadoulakis V., Tsakiris, K., Koussouris T., Kalogerakis N., Koukaras K., Chatzinikolaou A. and Theodoropoulos K. (2010), Water Framework Directive Implementation in Greece: Introducing Participation in Water Governance - the Case of the Evrotas River Basin Management Plan, Env. Pol. Gov., 20, 336-349.

Gerasidi A. (2004) Water Resources Management Options Assessment in Paros Island, Greece. Master Thesis at Systems of Energy and Environmental Management Master Programme, Department of Industrial Management, University of Piraeus, Greece (in Greek).

Global Water Partnership (2000) Integrated Water Resources Management, TAC Background Papers No 4, Technical Advisory Committee.

Global Water Partnership (2002) IWRM Toolbox: A Toolbox to Support IWRM, Global Water Partnership, Stockholm, Sweden.

Grigg N. (1996) Water resources Management: Principles, Regulations and Cases, Colorado State University.

Karavitis C.A. (1999) Decision Support System for Drought Management Strategies in Metropolitan Athens, Water International, 24(1), 10-21.

Karavitis C.A. and Kerkides P. (2002) Estimation of the Water Resources Potential in the Island System of the Aegean Archipelago, Greece, Water International, 27(21), 243-254.

Katsiardi P., Manoli E., Karavitis C. and Assimacopoulos D. (2005) Scenario-Based Strategy Development for Integrated Water Management, Global Nest Journal, 7(3), 360 - 368.

Kavadias A. (2008) Water Resources Management Strategies with the Application of Decision Support Systems for Cost Recovery in Ikaria Island, Greece. Master Thesis at the Department of Natural Resources Management and Agricultural Engineering, Agricultural University of Athens, Greece (in Greek).

Kyriazopoulou I.M. and Tselendis I. (2003) Difficulties in the Application of Water Framework Directive 2000/60 in Greece, Ecopolis A.E., NAMA A.E.

Manoli E., Arampatzis G., Pissias E., Xenos D. And Assimacopoulos D. (2002) Water Demand and Supply Analysis Using a Spatial Decision Support System, Global Nest: the Int. J., 3, 199-209.

Manoli E., Katsiardi P., Arampatzis G. and Assimacopoulos D. (2005) Comprehensive Water Management Scenarios for Strategic Planning, Global Nest Journal, 7(3), 369 - 378.

Michos D. (2004) Water Resources Management in Island Systems: Irrigation Supply Options in Syros Island, Greece. Master Thesis at Systems of Energy and Environmental Management Master Programme, Department of Industrial Management, University of Piraeus, Greece (in Greek).

Mysiak J., Giupponi C., Rosato P. and Cojocaru G. (2002) Beyond Developing a Decision Support System for Water Resource Management. MULINO Conference on European policy and tools for sustainable water management, 21-23 November 2002, Venice, Italy.

National Center for the Environment and Sustainable Development (2001) Water Resources Management Issues, Workshop No. 11.

Papamanthos C. (2007) Integrated Water Resources Management Strategies with the Application of Decision Support Systems in Sensitive Island Landscapes. Master Thesis at the Department of Natural Resources Management and Agricultural Engineering. Agricultural University of Athens, Greece (in Greek).

The WaterStrategyMan DSS (2004) A Comprehensive Decision Support System for the Development of Sustainable Water Management Strategies. Deliverable No 21.4 of the project 'Developing Strategies for Regulating and Managing Water Resources and Demand in Water Deficient Regions', EU DG Research, EVK1-CT-2001-00098. URL: http://environ.chemeng.ntua.gr/wsm/

Tatsis L. (2008) The WFD implementation in Greece: problems and prospects. Prosanatolismoi On-line Magazine, http://www.prosanatolismoi.gr/main/index.php?option=com_content\&task=view\&id=171\&ltemid=1 (accessed 6 November 2009).

Turban E. (1995) Decision Support and Expert Systems, Fourth Edition. Management Support Systems. Prentice-Hall, Inc

Zervas G., Kalaisakis P. and Feggeros K. (2000) Nutrition of Agricultural Animals. Stamoulis Editions, Athens, Greece (in Greek). 